\title{
KARAKTERISTIK KEPEMIMPINAN PT ENERGI SEJAHTERA MAS DUMAI
}

\author{
${ }^{1}$ Syukra Vadhillah dan ${ }^{2}$ Tobari \\ ${ }^{1}$ Guru SD Negeri 22 Magek, Kecamatan Kamang Magek, Kabupaten Agam. \\ e-mail: fsyukraf@gmail.com \\ ${ }^{2}$ Dosen Program Studi Magister Manajemen Pendidikan \\ Universitas PGRI Palembang \\ e-mail: kurnia.aprima@gmail.com
}

\begin{abstract}
This qualitative research was done to describe the leadership characteristic of PT Energi Sejahtera Mas Dumai. We used interview and documentation to collect the data. The interview was done with the two ESM officers. The documentation was done to record the interview. The results obtained indicate that the leader of ESM had the following characters: charismatics, respect to people, discipline, wisdom, sincere, empowering unity, developing officers' responsibility, encouragingi, and emphaty.
\end{abstract}

Keyword: Leadership Characteristic, PT Energi Sejahtera Mas, Dumai

\section{PENDAHULUAN}

$$
\text { Energi Sejahtera Mas (ESM) }
$$

merupakan perusahaan internasional yang memproduksi bahan dasar industri seperti Fatty Acid, Fatty Alcohol dan Gliserin. ESM merupakan salah satu bagian dari Sinarmas Group yang merupakan salah satu perusahaan pengelola kelapa sawit yang terbesar dan terintegrasi secara modern di Indonesia. Perusahaan yang baru berdiri pada tahun 2012 ini telah memiliki lebih dari 250 orang pegawai. Dengan luas lokasi perusahaan mencapai 24 hektar di wilayah Lubuk Gaung Zona Industri Kec. Sungai Sembilan, Dumai, Riau.

$$
\text { Walaupun proses produksi }
$$
perusahaan ini belum jalan namun pemimpinnya telah banyak melakukan berbagai hal untuk persiapan jalannya produksi. Di antara kegiatan yang dilakukannya ialah study banding ke PT Soci Mas Medan. Kemudian untuk menjaga kinerja pegawainya, pimpinan mengadakan outbond selama beberapa hari. Yang mana kegiatan itu dilakukan untuk mengasah kemampuan kerja pegawai. Ini merupakan suatu persiapan yang cukup matang yang dilakukan pimpinan ESM sebelum para pegawai langsung terjun ke lapangan.

Mendengar deskripsi tentang perusahaan ini, penulis merasa tertarik untuk mengetahui karakter pimpinan ESM. Bagaimana pun pemimpin merupakan salah satu faktor penentu kesuksesan sebuah organisasi/lembaga. Sebab menurut Priansa dan Somad (2014) pemimpin adalah orang yang paling berorientasi hasil, di mana hasil tersebut akan diperoleh jika pemimpin 
mengetahui apa yang diinginkannya. Jika pemimpin mengetahui apa yang diinginkannya sesuai dengan tujuan lembaga yang dipimpinnya maka ia telah mencapai kesuksesan. Tidak terkecuali besar kecilnya perusahaan, tidak memandang sudah lama atau baru berdirinya perusahaan tersebut.

\section{KARAKETRISTIK KEPEMIMPINAN}

Kepemimpinan menurut Robbins (2006) adalah kemampuan untuk mempengaruhi kelompok menuju pencapaian sasaran. Kepemimpinan menurut Kouzes dan Posner (2004) adalah penciptaan cara bagi orang untuk ikut berkontribusi dalam mewujudkan sesuatu yang luar biasa. Kepemimpinan menurut Tzu dan Cleary (2002) adalah sebuah persoalan kecerdasan, kelayakan untuk dipercaya, kelembutan, keberanian dan ketegasan. Kartono (2005) menyatakan kepemimpinan adalah kemampuan untuk memberikan pengaruh yang konstruktif kepada orang lain untuk melakukan satu usaha kooperatif mencapai tujuan yang sudah direncanakan. Rivai (2004) menyatakan kepemimpinan adalah peranan dan juga suatu proses untuk mempengaruhi orang lain. Dan Quible (2005) mengemukakan kepemimpinan adalah kemampuan seseorang untuk menyelesaikan sesuatu melalui dan dengan menggunakan orang lain.
Canon (1982) mendefinisikan kepemimpinan adalah kemampuan atasan mempengaruhi perilaku bawahan maupun perilaku kelompok organisasi. Pendapat ini menurut Sagala (2011) berdasarkan pada a) penekanan kepribadian, kemampuan pemimpin; b) memberi penekanan pada kegiatan, kedudukan dan perilaku pemimpin; c) memberi penekanan pada proses interaksi antara pemimpin, bawahan dalam situasi tertentu. Kemudian Yukl (1994) mengatakan kepemimpinan adalah proses mempengaruhi, memerintah secara persuasif, memberi contoh dan bimbingan kepada orang lain untuk mencapai tujuan yang telah ditetapkan. Dari pengertian ini, Sagala (2011) menyimpulkan bahwa hal penting mengenai komponen kepemimpinan ialah a) rangkaian tindakan; b) mempengaruhi dan memberi teladan; c) memberi perintah dengan cara persuasi dan manusiawi; d) pengikut mematuhi perintah; e) menggunakan authority dan power; f) menggerakkan atau mengerahkan semua personel dalam lembaga guna menyelesaikan tugas sehingga tujuan pun tercapai, hubungan kerja meningkat, menjalin kerja sama, menggerakkan sumber daya organisasi dan memberi motivasi kerja.

Danim dan Suparno (2009) menyatakan bahwa kepemimpinan adalah kemampuan mempengaruhi dan memberi arah yang terkandung di dalam diri pribadi 
pemimpin. Suprayogo (1999) kepemimpinan adalah proses mempengaruhi aktivitas individu atau kelompok untuk mencapai tujuan-tujuan tertentu dalam situasi yang telah ditetapkan. Bafadal (2003) kepemimpinan adalah keseluruhan proses mempengaruhi, mendorong, mengajak, dan menggerakkan serta menuntun orang lain dalam proses kerja agar berpikir, bersikap, dan bertindak sesuai dengan aturan yang berlaku dalam mencapai tujuan yang telah ditetapkan.

Dengan merujuk pada pengertian kepemimpinan menurut beberapa ahli di atas, maka Andang (2014) mengemukakan bahwa hakikat kepemimpinan meliputi 1) proses mempengaruhi atau memberikan contoh dari pemimpin pada bawahannya; 2) mengarahkan orang dengan cara kepatuhan, keperayaan, kehormatan dan kerja sama; 3) kemampuan untuk mempengaruhi, menginspirasi dan mengarahkan tindakan bawahan; 4) melibatkan tiga hal yaiu pemimpin, pengikut dan situasi tetentu; dan 5) kemampuan untuk mempengaruhi suatu kelompok untuk mencapai tujuan. Elemen yang menjadi syarat terjadinya proses kepemimpinan menurut Sagala (2011) ialah 1) adanya pemimpin (leader); 2) adanya pengikut (follower); dan 3) adanya aktivitas mempengaruhi berlangsung dalam situasi tertetu.
Pemimpin menurut Kouzes dan Posner (2004) adalah pionir, sebagai orang yang bersedia melangkah ke dalam situasi yang tidak diketahui. Seorang pemimpin Sedangkan menurut Kartono (2005) pemimpin adalah seorang pribadi yang memiliki superioritas tertentu sehingga dia memiliki kewibawaan dan kekuasaan untuk menggerakkan orang lain melakukan usaha bersama guna mencapai sasaran tertentu.

Kartono (1988) menyatakan bahwa untuk menjadi pemimpin harus mempunyai 1) kekuasaan, yaitu kekuatan, otoritas, legalitas untuk mempengaruhi dan menggerakkan bawahan untuk berbuat sesuatu; 2) kewibawaan, yaitu kelebihan, keunggulan, keutamaan, sehingga mampu mengatur orang lain untuk patuh pada pemimpin dan bersedia melakukan perbuatan-perbuatan tertentu; dan 3) kemampuan, yaitu segala daya, kesanggupan, kekuatan dan kecakapan ketrampilan teknis ataupun sosial yang dianggap melebihi kemampuan anggota biasa.

Menurut Atmadja (2012), karakter kepemimpinan adalah kualitas personal dari seorang pemimpin yang terbentuk melalui akumulasi tindakan-tindakan yang mengacu kepada nilai-nilai moralitas dan etika (moral/ethical values) yang diyakini oleh seorang pemimpin. 
Menurut Atmadja (2012) ada lima karakter kepemimpinan yang kemudian dikelompokkan dalam tiga tingkatan sebagai berikut 1) dimensi spiritual terdiri dari selfless (ikhlas) dan honesty (kejujuran); 2) dimensi emosional terdiri dari respect (menghargai) dan empathy (memahami); dan 3) dimensi rasional yaitu pursuit of exellence (sikap mental untuk mencapai hasil yang terbaik).

Adapun kelima karakter yang dikemukakan oleh Atmadja (2012) tersebut ialah sebagai berikut.

1. Selflessness (ikhlas), misi hakiki seorang pemimpin adalah melayani orang-orang yang dipimpinnya dan menjadikan mereka lebih baik. Pemimpin harus tulus dan ikhlas mengontribusikan kepemimpinannya murni untuk kepentingan para bawahannya dan organisasi yang dipimpinnya. Motivasi paling dasar dari seorang pemimpin adalah spirit of giving (spirit untuk selalu memberi) kepada orang-orang yang dipimpinnya tanpa mengharapkan timbal balik;

2. Honesty (kejujuran) merupakan sumber seluruh kebaikan dari sebuah kepemimpinan, sumber terwujudnya kepercayaan dalam sebuah organisasi, sumber terbentuknya standar moral dan etika yang kokoh. Ketika masing-masing pemimpin, masing-masing anggota organisasi bersikap jujur, maka tidak ada saling curiga, saling menjatuhkan, saling memfitnah, dan sebagainya, sehingga akan tercipta komunikasi yang transparan dan terbuka;

3. Respect to people (menghargai harkat dan martabat kemanusiaan), pemimpin harus menghargai bawahannya sebagai manusia dalam bentuk memberikan perhatian yang utuh kepada bawahannya. Karena setiap manusia memiliki berbagai kelemahan, kelebihan, maupun potensi masingmasing. Karakter kepemimpinan respect to people menuntut pemimpin memperlakukan bawahannya sebagai manusia seutuhnya (holistic human) dengan berbagai dimensi kehidupannya, mulai dari kehidupan keluarganya (family life), profesional (professional life), sosial (social life) sampai kepada kehidupan spiritualnya (spiritual life). Hanya dengan hal itulah potensi manusia dapat dilepaskan secara total dan kinerja dapat dipacu untuk menghasilkan kinerja terbaik;

4. Emphaty (empati) adalah kemampuan dan kapasitas seorang pemimpin dalam memahami dan merasakan emosi orangorang yang dipimpinnya. Dengan berempati, pemimpin akan terus mengasah ketajaman dalam membangun hubungan dan mengelola orang. Untuk 
dapat berempati, kemampuan pertama yang harus dimiliki pemimpin adalah mendengarkan yaitu mendengarkan katakata, bahasa tubuh, tekanan suara, atau emosi-emosi tersembunyi di balik ucapanucapan bawahannya melalui telinga, mata, dan yang terpenting mendengarkan dengan hati. Kemampuan kedua yang harus dimiliki untuk berempati adalah pemimpin harus hadir ditengah-tengah bawahannya, turun ke lapangan bersama mereka. Bawahannya ingin didengarkan, dilihat, berinteraksi dan merasakan langsung kepemimpinan anda. Dengan demikian mereka akan merasa berharga, merasa dimanusiakan, merasa berarti di depan anda. Yang ketiga pemimpin harus memiliki perhatian serius terhadap isu-isu dan persoalan-persoalan personal dari bawahannyanya. Tujuannya untuk menunjukkan bahwa pemimpin peduli pada bawahannyanya. Terakhir emphatic leader juga harus piawai dalam memberikan pengakuan dan penghargaan kepada bawahannya, yang merupakan mekanisme untuk membesarkan hati bawahannya, menunjukkan bahwa kontribusi yang mereka berikan diakui, dihargai, dan sangat berarti bagi organisasi. Hal ini akan memberi bawahannya energi untuk mewujudkan misi dan tujuan perusahaan; dan
5. Pursuit of exellence (sikap mental untuk mencapai hasil yang terbaik) akan memberikan bekal bagi pemimpin dalam mengelola bawahannyanya untuk mencapai kinerja luar biasa dalam mewujudkan misi dan tujuan perusahaan. Untuk dapat mencapai hasil terbaik, pemimpin harus mempunyai standar kinerja tertinggi yang diterapkan kepada dirinya maupun kepada bawahannyanya, baik dari sisi proses maupun dari sisi hasil yang dicapai. Pemimpin menggunakan standar kinerja tertinggi sebagai mekanisme untuk memberikan tantangan dan dorongan agar bawahannyanya tidak terjebak dalam zona kenyamanan. Pursuit of excellence memberikan energi yang tak pernah habis bagi pemimpin untuk terus belajar, terus memperbaiki diri, dan adaptif dalam menghadapi berbagai perubahan. Sikap inilah yang memungkinkan organisasi untuk maju dan terus berkembang.

Berbagai karakter yang dimiliki oleh pemimpin tersebut akan mempengaruhi keberhasilan kepemimpinan seorang pemimpin dalam memimpin suatu lembaga. Menurut Andang (2014) keberhasilan kepemimpinan dipengaruhi oleh dua faktor yaitu faktor internal dam faktor eksternal. Faktor internal adalah hal-hal yang bersumber dari dalam diri pemimpin itu 
sendiri sebagai penentu keberhasilan kepemimpinannya. Sedangkan faktor eksteral adalah hal-hal yang berkaitan dengan yang ada di luar diri pemimpin yang mempengaruhi keberhasilan kepemimpinan seorang pemimpin.

Adapun pemimpin yang sukses menurut konsep Ordweay Tead (Kartono, 2005) ialah 1) memberi perintah; 2) memberi celaan dan pujian; 3) memupuk tingkah laku pribadi yang benar; 4) peka terhadap saran dan nasehat; 5) memperkuat rasa kesatuan kelompok; 6) mengembangkan rasa tanggung jawab; dan 7) membuat keputusan yang bernilai dan tepat pada waktunya (Priansa dan Somad, 2014). Sedangkan pemimpin yang efektif menurut Sagala (2011) ialah pemimpin yang anggotanya dapat merasakan bahwa kebutuhan mereka terpenuih baik kebutuhan bekerja, motivasi, rekreasi, kesehatan, sandang, pangan, tempat tinggal, maupun kebutuhan lain yang pantas didapatkannya.

$$
\text { Zainun (1989) selanjutnya }
$$

menyatakan bahwa setiap pemimpin akan berhasil memimpin suatu organisasi apabila mempunyai syarat-syarat sebagi berikut yaitu: 1) mempunyai kecerdasan yang cukup tinggi untuk memikirkan dan mencarikan pemecahan setiap persoalan yang timbul dengan cara yang tepat, bijaksana dan memungkinkan untuk dilaksanakan; 2) mempunyai emosi yang stabil, tidak mudah diombang-ambingkan oleh suasana yang senantiasa berganti-ganti dan dapat memisahkan antara persoalan pribadi, rumah tangga, dan organisasi; 3) mempunyai kepandaian dalam menghadapi manusia dan mampu membuat bawahan merasa betah, senang dan puas dalam bekerja; 4) mempunyai keahlian untuk mengorganisir dan menggerakkan bawahan secara bijaksana dalam meujudkan tujuan organisasi serta mengetahui dengan tepat kapan dan kepada siapa tanggung jawab dan wewenang didelegasikan; dan 5) pemimpin juga harus mempunyai a) keterampilan sosial, yaitu keterampilan untuk memecahkan masalahmasalah yang timbul dalam suatu masyarakat, dan b) keterampilan manajemen, yaitu keterampilan dalam menggunakan metode, teknik dan peralatan untuk melaksanakan tugas tertentu (keterampilan teknikal), kemampuan untuk memahami motivasi dan bekerja sama dengan orang lain (keterampilan manusiawiah), dan kemampuan untuk memahami kompleksitas organisasi dan bertindak sesuai dengan tujuan menyeluruh organisasi (keterampilan konsepsional).

\section{METODE PENELITIAN}

Adapun metode yang digunakan dalam penelitian ini adalah penelitian 
kualitatif. Menurut Arikunto

penelitian kualitatif adalah penelitian yang bertujuan untuk menggambarkan apa adanya tentang sesuatu atau keadaan. Jenis penelitian ini dipilih karena memang penelitian ini dilakukan untuk mengetahui fenomena yang ada sebenarnya di lapangan tanpa adanya hal yang dibuat-buat atau dikondisikan oleh peneliti sebagaimana mestinya. Penelitian ini dilakukan untuk mengetahui bagaimana proses pembelajaran yang berlangsung sehingga visi dan misi sekolah dapat dicapai dengan baik.

Informan adalah orang yang mengerti tentang hal yang diteliti dan bersedia memberikan informasi tentang hal yang diteliti tersebut. Informan dalam penelitian kualitatif juga dapat disebut dengan sampel sumber data. Sumber data yang digunakan bersifat snowball sampling. Menurut Arikunto (2010) snowball sampling artinya peneliti mencari dari informan tersebut, peneliti mencari subjek-subjek lain secara terus-menerus sampai peneliti merasa jenuh karena sudah tidak menemukan lagi subjek yang tepat. Dalam snowball sampling informan dipilih langsung sesuai dengan maksud dan tujuan penelitian yang dilakukan. Jadi, peneliti akan berhenti melakukan pengumpulan data dan informasi jika informasi atau data yang diperoleh dari orang-orang yang dianggap memenuhi syarat memiliki kesamaan data. Dan peneliti tidak menemukan lagi subjek atau informan lain yang patut dijadikan sumber data. Jika penelitian tentang pengelolaan pembelajaran maka yang menjadi informan kunci ialah kepala sekolah dan guru.

Untuk mengumpulkan data, peneliti menggunakan wawancara dan dokumentasi. Dalam hal wawancara, peneliti mewawancarai 2 orang pegawai perusahaan. Kemudian dalam dokumentasi, peneliti merekam kegiatan wawancara dalam bentuk rekaman suara (mp3) yang digunakan sebagai penguat data sekaligus bukti bahwa memang penelitian itu dilakukan.

\section{HASIL PENELITIAN DAN PEMBAHASAN}

Pemimpin memberikan perintah pada bawahannya jika ada pekerjaan yang harus diselesaikan seperti membuat laporan. Dan pegawai pun mau mengerjakan perintah pimpinan karena sudah menjadi tanggung jawab pegawai itu, jika tidak dipatuhi pegawai juga yang susah. Selain itu pegawai menuruti perintah pimpinan juga karena segan, menghargainya sebagai pemimpin. Ini menunjukkan bahwa pemimpin ESM memiliki karakter berwibawa sehingga bawahannya melakukan perintahnya sesuai dengan pendapat Kartono (1988). Ini juga 
menunjukkan bahwa pemimpin ESM sukses mengatur bawahannya.

Kemudian bagi pegawai yang bekerja sesuai dengan SOP atau melebihi SOP yang berlaku akan mendapat nilai yang bagus. Penilaian itu akan mempengaruhi kenaikkan gaji, kenaikan golongannya, dijanjikan kenaikan pangkat, promosi, dan diberi bonus yang setimpal. Ini menunjukkan bahwa pemimpin ESM memiliki karakter respect to people sesuai dengan pendapat Atmadja (2012). Rasa menghargai itu juga dibuktikan ketika pegawai mengemukakan pendapat maka pimpinan mendengarkan, diterimanya dikembalikan ke forum. Pegawai diberikan kebebasan dalam mengemukakan pendapat. Sama halnya dengan sanggakan atau kritikan atas pendapatnya. Jika ada sanggahan terhadap perkataan pimpinan maka tidak mau menerima sanggahan itu, jika dia lebih memahami persoalannya. Jika sanggahan itu sesuai dengan pikiran pimpinan maka diterimanya. Tetapi ketika disanggah pimpinan tidak marah. Sanggahan itu harus ada alasannya jika alasannya itu bisa diterima maka pendapat kita diterima namun bila sanggahan itu lari dari persoalan maka sanggahan kita itu ditolak. Ini tidak hanya menunjukkan pimpinan ESM memiliki karakter respect tetapi juga peka terhadap saran sesuai dengan konsep Ordweay Tead (Kartono, 2005).
Selain itu pemimpin harus memiliki karakter Pursuit of exellence Atmadja (2012). Salah satu karakter pursuit of exellence itu ialah disiplin. Pimpinan ESM selalu datang ke tempat kerja pas jam kerja yaitu 08.30. Pimpinan pulang pas jam kerja, jika pekerjaannya masih banyak maka dia lembur, jika pekerjaannya sudah selesai maka dia pulang tapi biasanya pimpinan itu lebih sering terlambat pulang. Ini menunjukkan bahwa pimpinan ESM memiliki karakter disiplin.

Jika pegawai terlambat datang ke tempat kerja maka dipanggil, ditanya alasan keterlambatan, tidak langsung menilai buruk dan diberi nasehat, jika masih terlambat maka diberi SP. Ini menunjukkan bahwa pimpinan ESM memiliki karakter bijaksana hal ini sesuai dengan pendapat Zainun (1989). Selain itu, pimpinan ESM juga menerapkan hukuman atau peringatan secara bertahap yang menunjukkan karakter kebijaksanaannya. Hal ini terbukti bila peraturan dilanggar maka pimpinan memberikan peringatan, pemberitahuan kemudian jika sudah berkali-kali diberikan SP (surat peringatan) dari SP 1 sampai SP 3 jika masih melanggar maka dikeluarkan/menunggu sesuai keputusan atasan.

Selain itu, jika ada pegawai yang tidak memahami pekerjaannya maka pegawai 
itu bertanya pada pimpinan. Pimpinan mengajarkan sendiri hal-hal yang tidak dimengerti oleh pegawainya bahkan ia menawarkan dan menganjurkan agar setiap pegawai bertanya langsung padanya jika ada keraguan. Mereka terbuka untuk berbagi ilmu dengan senang hati tanpa keterpaksaan. Ini tidak hanya menunjukkan pimpinan ESM memiliki rasa ikhlas yang tinggi dalam membimbing bawahannya. Realita ini sesuai dengan teori Atmadja (2012).

Jika ada pegawai yang kesulitan mengerjakan pekerjaannya maka pekerjaan itu dikerjakan bersama-sama. Tidak dibiarkan pegawainya kesulitan sendiri bekerja inilah tim yang solid. Tetapi jika pekerjaan itu masih bisa dikerjakan sendiri maka tetap dikerjakan sendiri. Mereka memberikan solusi misalnya diajari, dipindahkan ke bagian pekerjaan lain yang lebih dikuasainya pegawai mengalami kesulitan dalam bekerja. Ini menunjukkan bahwa pimpinan ESM memiliki karakter memperkuat rasa kesatuan kelompok yang terdapat dalam konsep pemimpin yang sukses Ordweay Tead (Kartono, 2005). Hal itu juga diperkuat dengan keakraban antara bawahan dan pimpinan ketika bertemu di luar jam dan tempat kerja. Ketika bertemu adanya aling menyapa, bercerita tentang persoalan di luar persoalan pekerjaan.
Jika pimpinan ada keperluan sehingga dia tidak bisa menyampaikan materi diskusi di depan maka diserahkan kepada bawahannya yang dianggap mampu untuk menyampaikan materi diskusi. Ini menunjukkan bahwa pimpinan ESM memiliki karakter mengembangkan rasa tanggung jawab bawahannya yang terdapat dalam konsep pemimpin yang sukses Ordweay Tead (Kartono, 2005). Hal itu ditmbah lagi dengan diadakannya musyawarah untuk mengatasi dan mencari solusi atas suatu masalah pekerjaan. Pimpinan tidak memutuskan sendiri persoalan yang sedang dihadapi.

Karakter memenuhi kebutuhan motivasi bawahannya juga dimiliki oleh pimpinan ESM. Ini terbukti jika ada pegawai tidak lagi bersemangat melakukan pekerjaannya maka pimpinan memberi dorongan dengan memperingatkan konsekuensi ketika pegawai malas agar di rajin bekerja kembali. Ditanya tentang ketidaksemangatan pegawai dalam bekerja. Ini sesuai dengan teori Sagala (2011).

Rasa empati juga diterapkan pimpinan ESM dalam memimpin perusahaan. Empati menurut Atmadja (2012) adalah kemampuan dan kapasitas seorang pemimpin dalam memahami dan merasakan emosi orang-orang yang dipimpinnya. Ini terbukti ketika pegawai minta izin karena ada 
keperluan maka diperbolehkan sekitar 4 jam jika memang alasan keperluannya itu dapat diterima. Harus ada alasan tentang ketidakhadiran kita, jika alasannya dapat diterima maka diperbolehkan. kalaupun sakit tidak dipotong gaji asalkan ada surat bukti sakit. Lalu ketika pegawai sakit mendadak di tempat kerja maka disuruh pulang berobat, atau dibawa ke klinik di tempat kerja sebagai pengobatan sementara yang tersedia di perusahaan. Begitu juga ketika ada konflik antar pegawai maka diselesaikan pimpinan dengan SP. Jika masalah intern maka pimpinan tidak mau juga ikut campur dalam masalahnya tapi jika masih dalam urusan pekerjaan maka pimpinan turun tangan untuk mencari tahu penyebabnya dan menyelesaikannya. Kemudian dalam urusan pekerjaan, jika ada masalah yang penting maka pimpinan turun langsung ke lapangan untuk membantu menyelesaikannya. Pimpinan turun ke lapangan jika ada gangguan.

\section{KESIMPULAN}

Pemimpin ESM memiliki karakter ebagai berikut: berwibawa, respect to people, disiplin, bijaksana, ikhlas, memperkuat rasa kesatuan, mengembangkan rasa tanggung jawab bawahannya, memotivasi, dan empati. Dngan berkembangnya karakter ini pada diri pemimpin ESM akan membawa kesuksesan PT ESM itu sendiri.

\section{DAFTAR PUSTAKA}

Andang. (2014). Manajemen dan Kepemimpinan Kepala Sekolah: Konsep, Strategi, dan Inovasi Menuju Sekolah Efektif. Yogyakarta: Ar-Ruzz Media.

Arikunto, Suharsimi. (1993). Manajemen Penelitian. Jakarta: Rineka Cipta.

(2010). Prosedur Penelitian. Jakarta: PT Rineka Cipta.

Atmadja, Stanley S. (2012). Inside the Giant Leap: How Abundance Mind Creates Performing Climate to Achieve Extraordinary Result. Jakarta: Gramedia Pustaka Utama.

Bafadal, Ibrahim. (2003). Manejemen Mutu Sekolah Inklusif. Malang: Bayumedia Publishing.

Danim dan Suparno. (2009). Manajemen dan Kepemimpinan Transformasional Kekepalasekolahan. Jakarta: Rineka Cipta.

Kartono, Kartini. (1988). Pemimpin dan Kepemimimpinan: Apakah Pemimpin Abnormal Itu? Jakarta: Rajawali.

\section{(2005). Kepemimpinan:} Apakah Kepemimpinan Abnirmal Itu? Jakarta: PT Raja Grafindo Persada.

Kouzes dan Posner. (2004). Leadership the Challenge. Jakarta: Erlangga.

Pramudjo, Anung. (2013). Implementasi Manajemen Kepemimpinan dalam Pencapaian Tujuan Organisasi. JBMA Vo. I No. 2 Faberuari 2013. 
Yogyakarta: Akademi Manajemen Administrasi (AMA).

Priansa, Donni Juni dan Rismi Somad. (2014). Manajemen Supervisi dan Kepemimpinan Kepala Sekolah. Bandung: Alfabeta.

Quible, Zane K. (2005). Administrative Office Management. New York: Pearson Prentice.

Rivai, Veithzal. (2004). Kiat Kepemimpinan dalam Abad ke 21. Jakarta: Murai Kencana.

Robbins, Stephen P. (2006). Teori Organisasi: Struktur, Desain, dan
Aplikasi alih bahasa oleh Yusuf Udaya. Jakarta: Arcan.

Sagala, Syaiful. (2011). Kemampuan Profesional Guru dan Tenaga Kependidikan. Bandung: Alfabeta.

Suprayogo, Imam. (1999). Reformasi Visi dan Misi Pendidikan Islam. Malang: STAIN Press.

Tzu, Sun dan Thomas Cleary. (2002). Seni Perang. Jakarta: Erlangga.

Zainun, Buchari. (1989). Manajemen dan Motivasi. Edisi Revisi. Jakarta: Balai Aksara. 